ISBN 978-93-86878-21-2

15th PHNOM PENH Int'l Conference on Food, Environmental, Biological \& Medical Sciences

(PFEBM-18)

Aug. 8-10, 2018 Phnom Penh (Cambodia)

\title{
Ion-ozone-cavitation treated barley "Baysheshek"
}

\author{
Talgat Kulazhanov, Auyelbek Iztayev, Madina Yakiyayeva* and Bauyrzhan Iztayev \\ Almaty Technological University Tole bi 100, Almaty, 050012, Kazakhstan
}

\begin{abstract}
The paper presents mathematical models of ion-ozone treatment without and with cavitation, describing changes in seed properties and technological qualities of barley "Baysheshek". To improve the quality of barley seed and products of its processing during storage, electrophysical processing methods were used on a universal experimental installation. Technologies and technologies of ion-ozone and ion-ozonecavitation installation for processing grain crops are optimized. As a result of the research, regression and optimal models were developed describing the interrelationships of the regime parameters with the parameters of grain properties and quality, and also the optimal technological regimes of ion-ozone and ion-ozone cavitation treatment are established in preparation for sowing, levels of quality and quality of cereals.
\end{abstract}

Keywords: ion, ozone, cavitation, grain, barley.

\section{Introduction}

At the basis of increasing the biological value of processed seed and food grains and obtaining the effect, structural and functional changes in the membrane formations of cells and intracellular organelles, which in our understanding are the targets of ion-ozone-cavitation [1-2].

As a result of this interaction, a physico-chemical basis is created to change the metabolic processes associated with the transfer of protons and electrons in the cell membranes, and on this basis, successive nonspecific reactions of the cell and the organism as a whole arise. Differences exist only in the biophysical subtleties of the interaction of ion-ozone-cavitation and biotissues [3].

The regulated effect on the biological environment of the ion-air-ion mixture with the use of ion-ozonecavitation allows intensive bubbling with activation and stimulation of biological media of crop production, as well as inhibiting viruses, bacteria, spore formations with the retention of physiological and physicochemical processes in them, suppression of their infectious activity.

To increase seed, productivity and technological properties of the grain at the short and long-term storage is effective ion-ozone processing of grain products in the flow of electrically charged particles, which allows to use the potential of biological and ecological resources [4].

In order to increase the efficiency of the use of crop production, Alamty technological university scientists developed various electrophysical methods for processing, storing and processing crop production: ion-ozone, ion-ozone-cavitation processing of crop production, which contribute to improving the quality and conservation of grain [5-6].

\section{Methods}

Experimental studies were carried out in accordance with the plan of full-factor experiments at room temperature $18-23^{\circ} \mathrm{C}$. In the ion-ozone treatment, the crops are loaded into an ion-ozone-cavitation unit prefilled with an ion-ozone mixture with an ozone concentration of $0.5 \mathrm{mg} / \mathrm{dm} 3$ to $4 \mathrm{mg} / \mathrm{dm} 3$ and the content of molecular ions in the range from 500 to $60000 \mathrm{unit} / \mathrm{cm} 3$. The ratio of ion concentration $(\mathrm{U} / \mathrm{cm} 3)$ to ozone 
concentration $(\mathrm{mg} / \mathrm{cm} 3) \mathrm{Ci} / \mathrm{o}$ is $(1-15)^{*} 106$ units/mg, i.e. 1-15 million units / mg. Further, for 10-20 minutes, ion-ozone ventilation of grains.

As factors influencing the properties and quality indicators of the barley, the following:

- the ratio of the ion concentration $(\mathrm{ppm} / \mathrm{cm} 3)$ to the ozone concentration $(\mathrm{mg} / \mathrm{cm} 3)$ million units / $\mathrm{mg}$;

- overpressure (for cavitation treatment) $\mathrm{P}$, ati;

- humidity of samples before treatment $\mathrm{w}, \%$;

- processing time $\tau 1$, min.

On the basis of the least squares studies performed, algorithms and programs of sequential regression analysis developed in the $\square \quad$ Odessa Technological Institute of Food Industry [7, 8] obtained regression equations, adequately (by the Fisher criterion) describing the dependencies of the above indices of the quality of the processed grain crops, respectively, on the conditions and regimes of their ion-ozone-cavitation and ioncavitation treatment.

The analysis of technological properties of grain crops was carried out in accordance with the following normative documents: GOST 12041-82 - Seeds of agricultural crops. Method for humidity determination; GOST 10968-88 - Grain. Methods for determining germination energy and germination capacity; GOST 10846-91 Grain and derivative products. Method for protein determination; ST RK GOST R 51411-2006 - Grain and derivative products. Ash determination; GOST 12042-84 - Mass of 1000 grains; ISO 5529: 1992 - Green Index; GOST 10845-98 - Grain and derivative products. Method for starch determination.

\section{Main Part}

Ozone and molecular ions contribute to oxidation-reduction processes in biological media. Transition of negative and positive ions from one substance to another means oxidation of the first and restoration of the second, which is accompanied by the acquisition or loss of energy potential. Oxidation-reduction abilities of ozone and ions contribute to metabolism. Including all the variety of reactions occurring in a living organism: oxidation, reduction, cleavage, integration of molecules, intermolecular transfer, etc. for the development of the cellular system [9-10].

The use of molecular ions has a positive effect on the germination, growth, productivity, preservation of a number of plants during presowing cultivation, growing, storage, including in greenhouses at any time of the year. In this paper, we present the results of studies on the use of ion-zone and ion-ozone-cavitation seedbed seed treatment in the field of cavitation with the aim of increasing the productivity, the viability of seeds and the technological properties of grain crops for the production of environmentally friendly products of processing.

In experimental studies, two methods of processing grain crops were studied:

1. Ion-ozone treatment of grain crops;

2. Ion-ozone-cavitation processing of grain crops.

The experiments were carried out under normal processing conditions - at room temperature $18-25^{\circ} \mathrm{C}$.

Quality indicators of control (unprocessed) cereal crops are given in Table 1. The matrices for planning experiments with the experimental conditions and the results of determining the quality indicators of the treated crops are given in Tables 2,3.

The regression equations obtained on the basis of processing the results of the experiments are given below in the corresponding mathematical models used in optimizing the processing regimes of the cultures studied. All the equations obtained adequately describe the experimental data. 
TABLE I: Quality indicators of control (unprocessed) samples of barley "Baysheshek"

\begin{tabular}{|c|c|c|c|c|c|c|c|c|c|c|}
\hline \multirow{5}{*}{$\begin{array}{l}\text { Samples } \\
\text { (cultivars } \\
\text { ) of crops }\end{array}$} & \multicolumn{3}{|c|}{ Seed properties } & \multicolumn{7}{|c|}{ Technological properties } \\
\hline & \multirow[b]{2}{*}{$\begin{array}{l}\text { Germinatio } \\
\mathrm{n} \text { energy } \\
\text { for } 3 \\
\text { days, } \%\end{array}$} & \multirow[b]{2}{*}{$\begin{array}{l}\text { Growth } \\
\text { capacit } \\
\text { y for } 5 \\
\text { days, } \\
\%\end{array}$} & \multirow[b]{2}{*}{$\begin{array}{l}\text { Germinatio } \\
\mathrm{n} \text { for } 7 \\
\text { days, } \%\end{array}$} & \multicolumn{4}{|c|}{ Physical } & \multicolumn{3}{|c|}{ Biochemical } \\
\hline & & & & $\begin{array}{l}\text { Moisture } \\
\text { before } \\
\text { treatment, } \\
\%\end{array}$ & $\begin{array}{l}\text { Nature } \\
, \mathrm{g} / 1\end{array}$ & $\begin{array}{l}\text { Density } \\
, \mathrm{g} / \\
\mathrm{cm}^{3}\end{array}$ & $\begin{array}{l}\text { Weigh } \\
t \text { of } \\
1000 \\
\text { grains, } \\
g\end{array}$ & $\begin{array}{c}\text { Mass } \\
\text { fraction } \\
\text { of } \\
\text { protein, } \\
\%\end{array}$ & $\begin{array}{c}\text { Starch, } \\
\%\end{array}$ & $\begin{array}{c}\text { Green } \\
\text { Index, } \\
\text { ml }\end{array}$ \\
\hline & \multicolumn{10}{|c|}{ Function Indicators } \\
\hline & $\mathrm{y}_{1}$ & $\mathrm{y}_{2}$ & $\mathrm{y}_{3}$ & $\mathrm{y}_{4}$ & $\mathrm{y}_{5}$ & $\mathrm{y}_{6}$ & $\mathrm{y}_{7}$ & $\mathrm{y}_{8}$ & $\mathrm{y}_{9}$ & $\mathrm{y}_{10}$ \\
\hline \multirow{2}{*}{$\begin{array}{l}\text { Barley } \\
\text { «Baishes } \\
\text { hek» }\end{array}$} & 97 & 98 & 100 & 12,66 & 642 & 1,12 & 49 & 9,59 & 65,03 & 32,12 \\
\hline & 97 & 98 & 98 & 18,94 & 614 & 1,11 & 52 & 5,57 & 57,87 & 29,81 \\
\hline
\end{tabular}

TABLE II: Conditions and results of full-factorial experiments of FFE-23 on ion-ozone treatment of barley "Baysheshek"

\begin{tabular}{|c|c|c|c|c|c|c|c|c|c|c|c|c|c|}
\hline \multirow{5}{*}{ 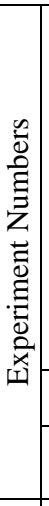 } & \multirow{3}{*}{$\begin{array}{l}\text { Ratio of } \\
\text { ion } \\
\text { concentrati } \\
\text { ons to } \\
\text { ozone, } \\
\text { million } \\
\text { units / mg }\end{array}$} & \multirow{3}{*}{$\begin{array}{c}\text { Moistur } \\
\text { e before } \\
\text { processi } \\
\text { ng, } \%\end{array}$} & \multirow{3}{*}{$\begin{array}{l}\text { Proces } \\
\text { sing } \\
\text { time, } \\
\text { min }\end{array}$} & \multirow{2}{*}{\multicolumn{3}{|c|}{ Seed properties }} & \multicolumn{7}{|c|}{ Technological properties } \\
\hline & & & & & & & \multicolumn{4}{|c|}{ Physical } & \multicolumn{3}{|c|}{ Biochemical } \\
\hline & & & & $\begin{array}{l}\text { Germina } \\
\text { tion } \\
\text { energy } \\
\text { for } 3 \\
\text { days, } \%\end{array}$ & $\begin{array}{l}\text { Gro } \\
\text { wth } \\
\text { capa } \\
\text { city } \\
\text { for } 5 \\
\text { days } \\
, \% \\
\end{array}$ & $\begin{array}{l}\text { Germi } \\
\text { nation } \\
\text { for } 7 \\
\text { days, } \\
\%\end{array}$ & $\begin{array}{l}\text { Moist } \\
\text { ure } \\
\text { before } \\
\text { treatm } \\
\text { ent, } \%\end{array}$ & $\begin{array}{l}\text { Nature } \\
, \mathrm{g} / \mathrm{l}\end{array}$ & $\begin{array}{l}\text { Densit } \\
\mathrm{y}, \mathrm{g} / \\
\mathrm{cm}^{3}\end{array}$ & $\begin{array}{l}\text { Wei } \\
\text { ght } \\
\text { of } \\
1000 \\
\text { grai } \\
\text { ns, g }\end{array}$ & $\begin{array}{c}\text { Mass } \\
\text { fraction } \\
\text { of } \\
\text { protein, } \\
\%\end{array}$ & $\begin{array}{c}\text { Starch, } \\
\%\end{array}$ & $\begin{array}{c}\text { Green } \\
\text { Index, } \\
\text { ml }\end{array}$ \\
\hline & \multicolumn{3}{|c|}{ Experimental conditions } & \multicolumn{10}{|c|}{ Quality indicators } \\
\hline & $\begin{array}{l}C_{\mathrm{i} / \mathrm{o}}, \mathrm{mln} . \\
\text { units/mg }\end{array}$ & $w, \%$ & $\tau$, min. & $\mathrm{y}_{1}$ & $\mathrm{y}_{2}$ & $\mathrm{y}_{3}$ & $\mathrm{y}_{4}$ & $\mathrm{y}_{5}$ & $\mathrm{y}_{6}$ & $\mathrm{y}_{7}$ & $\mathrm{y}_{8}$ & $\mathrm{y}_{9}$ & $\mathrm{y}_{10}$ \\
\hline 1 & 15 & 20 & 20 & 89 & 89 & 90 & 16,68 & 627 & 1,11 & 60 & 8,88 & 61,34 & 32,24 \\
\hline 2 & 1 & 20 & 20 & 86 & 88 & 89 & 17,32 & 622 & 1,12 & 62 & 8,15 & 61,05 & 32,54 \\
\hline 3 & 15 & 20 & 20 & 85 & 99 & 99 & 12,75 & 634 & 1,11 & 52 & 9,82 & 63,96 & 33,48 \\
\hline 4 & 1 & 20 & 20 & 89 & 99 & 99 & 12,72 & 638 & 1,09 & 46 & 9,60 & 64,24 & 33,27 \\
\hline 5 & 15 & 13 & 20 & 84 & 87 & 88 & 17,11 & 621 & 1,09 & 58 & 8,42 & 60,98 & 32,74 \\
\hline 6 & 1 & 13 & 20 & 86 & 87 & 89 & 17,47 & 614 & 1,11 & 60 & 8,78 & 61,34 & 33,15 \\
\hline 7 & 15 & 13 & 20 & 95 & 99 & 99 & 12,72 & 638 & 1,12 & 53 & 9,83 & 64,29 & 32,63 \\
\hline 8 & 1 & 13 & 20 & 92 & 99 & 99 & 12,64 & 635 & 1,09 & 46 & 9,85 & 64,19 & 34,03 \\
\hline
\end{tabular}


TABLE III: Conditions and results of full-factorial experiments of FFE- $2^{4}$ on the ion-ozone-cavitation processing of barley "Baysheshek"

\begin{tabular}{|c|c|c|c|c|c|c|c|c|c|c|c|c|c|c|}
\hline \multirow{5}{*}{ 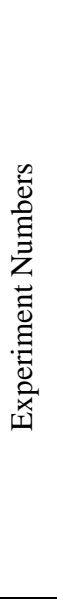 } & \multirow{3}{*}{$\begin{array}{c}\text { Ratio } \\
\text { of ion } \\
\text { concen } \\
\text { tration } \\
\text { s to } \\
\text { ozone, } \\
\text { million } \\
\text { units / } \\
\text { mg }\end{array}$} & \multirow{3}{*}{$\begin{array}{l}\text { Overp } \\
\text { ressur } \\
\mathrm{e} \\
\text { (cavit } \\
\text { ation), } \\
\text { ati }\end{array}$} & \multirow{3}{*}{$\begin{array}{l}\text { Moist } \\
\text { ure } \\
\text { before } \\
\text { proces } \\
\text { sing, } \\
\%\end{array}$} & \multirow{3}{*}{$\begin{array}{l}\text { Proces } \\
\text { sing } \\
\text { time, } \\
\text { min }\end{array}$} & \multirow{2}{*}{\multicolumn{3}{|c|}{ Seed properties }} & \multicolumn{7}{|c|}{ Technological properties } \\
\hline & & & & & & & & \multicolumn{4}{|c|}{ Physical } & \multicolumn{3}{|c|}{ Biochemical } \\
\hline & & & & & $\begin{array}{l}\text { Germi } \\
\text { nation } \\
\text { energy } \\
\text { for } 3 \\
\text { days, } \\
\%\end{array}$ & $\begin{array}{l}\text { Growt } \\
\text { h } \\
\text { capaci } \\
\text { ty for } \\
5 \\
\text { days, } \\
\%\end{array}$ & $\begin{array}{l}\text { Germi } \\
\text { nation } \\
\text { for } 7 \\
\text { days, } \\
\%\end{array}$ & $\begin{array}{l}\text { Moisture } \\
\text { before } \\
\text { treatmen } \\
\text { t, } \%\end{array}$ & $\begin{array}{l}\text { Natu } \\
\text { re, g } \\
/ 1\end{array}$ & $\begin{array}{l}\text { Den } \\
\text { sity, } \\
\mathrm{g} / \\
\mathrm{cm}^{3}\end{array}$ & $\begin{array}{l}\text { Wei } \\
\text { ght } \\
\text { of } \\
1000 \\
\text { grai } \\
\text { ns, g }\end{array}$ & $\begin{array}{c}\text { Mas } \\
\text { s } \\
\text { fract } \\
\text { ion } \\
\text { of } \\
\text { prot } \\
\text { ein, } \\
\% \\
\end{array}$ & $\begin{array}{c}\text { Starch, } \\
\%\end{array}$ & $\begin{array}{c}\text { Green } \\
\text { Index, } \\
\text { ml }\end{array}$ \\
\hline & \multicolumn{4}{|c|}{ Experimental conditions } & \multicolumn{10}{|c|}{ Quality indicators } \\
\hline & $\begin{array}{c}C_{\mathrm{i} / \mathrm{o}} \\
\text { mln. } \\
\text { units/ } \\
\mathrm{mg}\end{array}$ & $\begin{array}{c}P, \\
\text { atm. }\end{array}$ & $w, \%$ & $\tau, \min$. & $\mathrm{y}_{1}$ & $\mathrm{y}_{2}$ & $\mathrm{y}_{3}$ & $\mathrm{y}_{4}$ & $\mathrm{y}_{5}$ & $\mathrm{y}_{6}$ & $\mathrm{y}_{7}$ & $\mathrm{y}_{8}$ & $\mathrm{y}_{9}$ & $\mathrm{y}_{10}$ \\
\hline 1 & 15 & 4 & 20 & 20 & 92 & 93 & 93 & 17,57 & 615 & 1,11 & 57 & 8,10 & 61,19 & 35,42 \\
\hline 2 & 1 & 4 & 20 & 20 & 88 & 92 & 92 & 17,04 & 625 & 1,11 & 60 & 7,75 & 60,37 & 33,10 \\
\hline 3 & 15 & 1 & 20 & 20 & 85 & 87 & 89 & 17,44 & 615 & 1,11 & 56 & 8,03 & 61,15 & 33,53 \\
\hline 4 & 1 & 1 & 20 & 20 & 90 & 91 & 92 & 17,27 & 622 & 1,11 & 61 & 8,77 & 61,19 & 36,96 \\
\hline 5 & 15 & 4 & 13 & 20 & 98 & 98 & 99 & 12,64 & 635 & 1,11 & 49 & 9,41 & 64,15 & 34,45 \\
\hline 6 & 1 & 4 & 13 & 20 & 96 & 98 & 98 & 12,48 & 639 & 1,11 & 50 & 9,00 & 64,55 & 33,28 \\
\hline 7 & 15 & 1 & 13 & 20 & 98 & 99 & 99 & 12,75 & 632 & 1,11 & 48 & 9,26 & 63,83 & 35,89 \\
\hline 8 & 1 & 1 & 13 & 20 & 98 & 100 & 100 & 12,72 & 639 & 1,11 & 48 & 9,58 & 63,85 & 34,28 \\
\hline 9 & 15 & 4 & 20 & 10 & 91 & 91 & 91 & 17,51 & 618 & 1,11 & 60 & 8,26 & 60,64 & 35,76 \\
\hline 10 & 1 & 4 & 20 & 10 & 94 & 95 & 95 & 17,18 & 616 & 1,12 & 54 & 8,55 & 61,56 & 34,76 \\
\hline 11 & 15 & 1 & 20 & 10 & 97 & 98 & 98 & 17,43 & 621 & 1,11 & 53 & 8,33 & 60,83 & 33,27 \\
\hline 12 & 1 & 1 & 20 & 10 & 93 & 94 & 94 & 17,22 & 622 & 1,12 & 53 & 8,19 & 61,18 & 34,51 \\
\hline 13 & 15 & 4 & 13 & 10 & 96 & 97 & 97 & 12,8 & 634 & 1,11 & 49 & 9,19 & 63,74 & 32,52 \\
\hline 14 & 1 & 4 & 13 & 10 & 98 & 100 & 100 & 12,77 & 637 & 1,11 & 50 & 9,70 & 63,85 & 34,58 \\
\hline 15 & 15 & 1 & 13 & 10 & 98 & 99 & 99 & 12,77 & 631 & 1,11 & 50 & 9,59 & 64,27 & 33,49 \\
\hline 16 & 1 & 1 & 13 & 10 & 100 & 100 & 100 & 12,78 & 636 & 1,09 & 51 & 9,62 & 63,57 & 34,29 \\
\hline
\end{tabular}

Restrictions on the range of variation in the regime parameters of ion-ozone treatment of all the investigated cereal crops were as follows:

$1 \mathrm{mln}$. unit/mg $\leq C_{\mathrm{i} / \mathrm{o}} \leq 15 \mathrm{mln}$. unit $/ \mathrm{mg} ; 13 \% \leq w \leq 20 \% ; 10 \mathrm{~min} \leq \tau_{1} \leq 20 \mathrm{~min}$.

The mathematical model for optimizing the modes of ion-ozone treatment of barley of the barley «Baysheshek» has this form:

Seed properties:

- objective function:

$80 \leq \mathrm{y}_{1}=132,50-2,50 \cdot w-2,32 \cdot \tau+0,129 \cdot w \cdot \tau, \% \leq 100 \rightarrow \max ;$

- restrictions on quality indicators:

$85 \leq \mathrm{y}_{2}=119,89+1,61 \cdot w, \% \leq 100$;

$85 \leq \mathrm{y}_{3}=117,57-1,43 \cdot w, \% \leq 100$.

Physical properties:

- objective function

$1,0 \leq \mathrm{y}_{6}=1,105, \mathrm{~g} / \mathrm{cm}^{3} \leq 1,2 \rightarrow \max ;$

- restrictions on quality indicators:

$12,0 \leq \mathrm{y}_{4}=4,47+0,634 \cdot w, \% \leq 22,0 ;$ 
$600 \leq \mathrm{y}_{5}=(62,86) \cdot 10 \mathrm{~g} / \mathrm{l} \leq 650$

$45,0 \leq \mathrm{y}_{7}=16,55+1,59 \cdot C_{\mathrm{u} / \mathrm{o}}+2,23 \cdot \mathrm{w}-0,0867 \cdot C_{\mathrm{i} / \mathrm{o}} \cdot w, \mathrm{~g} \leq 65,0 ;$

Biochemical properties:

- objective function

$5,5 \leq \mathrm{y}_{8}=12,04-0,174 \cdot w, \% \leq 10,0 \rightarrow \max ;$

- restrictions on quality indicators:

$56,0 \leq \mathrm{y}_{9}=62,67, \% \leq 75,0$;

$28,0 \leq \mathrm{y}_{10}=33,01, \% \leq 35,0$.

The nature of the dependence of the energy of barley germination "Baysheshek" on the factors $\mathrm{w}$ and $\tau$ is shown in Figure 1. The remaining dependencies of objective functions on the investigated factors, as follows from mathematical models, do not need a graphical representation.

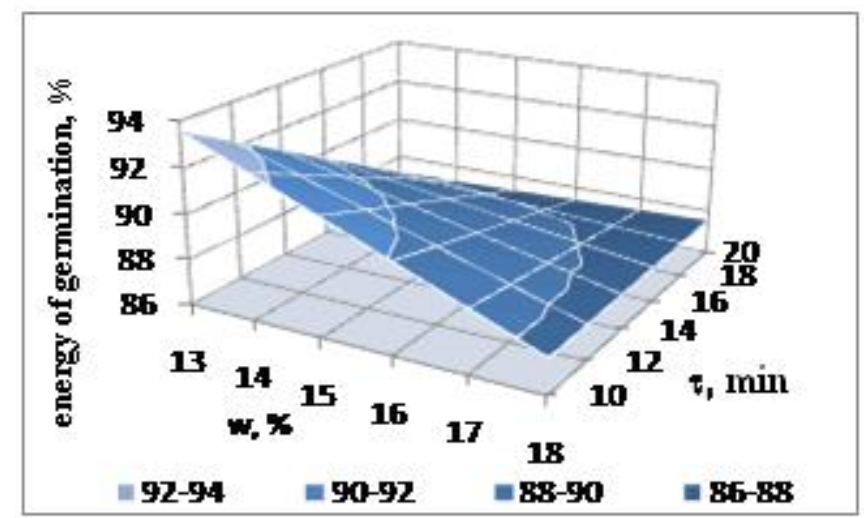

Fig. 1: Surfaces of the response of the dependence of the energy of barley germination "Baysheshek" on the factors w and $\tau$

The mathematical model for optimizing the modes of ion-ozone-cavitation processing of barley of the barley «Baysheshek» has this form:

Seed properties:

- objective function

$84 \leq \mathrm{y}_{1}=113,95-0,929 \cdot w-0,275 \cdot \tau, \% \leq 100 \rightarrow \max$

- restrictions on quality indicators:

$86 \leq \mathrm{y}_{2}=113,48-0,893 \cdot w-0,200 \cdot \tau, \% \leq 100$

$88 \leq \mathrm{y}_{3}=98,25+0,769 \cdot \tau-0,0557 \cdot w \cdot \tau, \% \leq 100$.

Physical properties:

- objective function

$1,0 \leq \mathrm{y}_{6}=1,11, \mathrm{~g} / \mathrm{cm}^{3} \leq 1,14 \rightarrow \max ;$

- restrictions on quality indicators:

$12,0 \leq \mathrm{y}_{4}=4,14+0,660 \cdot w, \% \leq 18,0 ;$

$600 \leq \mathrm{y}_{5}=627,3, \mathrm{~g} / 1 \leq 650$;

$47,0 \leq \mathrm{y}_{7}=35,68+1,05 \cdot w, \Gamma \leq 62,0$;

Biochemical properties:

- objective function

$7,0 \leq \mathrm{y}_{8}=11,59-0,167 \cdot w, \% \leq 11,0 \rightarrow \max ;$

- restrictions on quality indicators:

$55,0 \leq \mathrm{y}_{9}=62,49, \% \leq 67,0$;

$28 \leq \mathrm{y}_{10}=33,78-0,121 \cdot C_{\mathrm{i} / \mathrm{o}}+0,127 \cdot \tau+0,0434 \cdot C_{\mathrm{i} / \mathrm{o}} \cdot P-0,0321 \cdot P \cdot \tau, \% \leq 38$. 


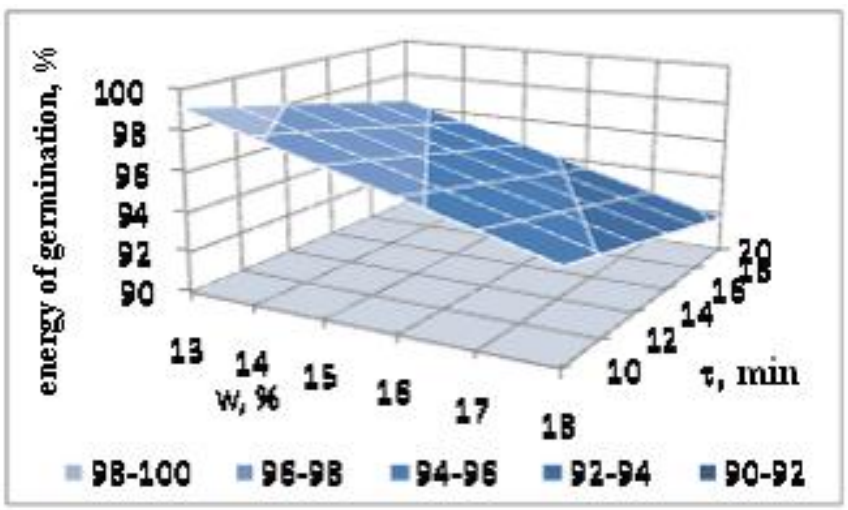

Fig. 2: Surfaces of the response of the dependence of the energy of barley germination "Baysheshek" on the factors w and $\tau$

From the mathematical models it can be seen that all the objective functions of barley have a simple character - the germination energy depends only on two factors (grain moisture and processing time), the density of barley grain does not change statistically (constant), and the mass fraction of the birch depends only on the moisture content of the grain. Therefore, the graphical dependence is presented only for the germination energy (Figure 2). It is seen that it inversely decreases inversely with increasing barley moisture and the duration of its treatment.

To compare the quality of control (unprocessed) samples of the studied cultures and the optimal parameters obtained after their ion-ozone (IO) and ion-ozone-cavitation (IOC) treatment.

Analysis of these tables showed that the optimum regimes of ion-ozone and ion-ozone-cavitation treatment to improve the considered seed, physical, biochemical, flour-milling properties and the state of preservation of grain are the same - optimal results were obtained when processing wet grain (20\%). For seed, physical, biochemical, flour-milling and state of preservation, the best results were obtained when processing dry grain $(13 \%)$.

The analysis of the obtained results also showed that the ratio of ion concentration to ozone concentration for practically all treatment regimes is 1 million units / $\mathrm{mg}$.

The pressure of cavitation and the duration of treatment for different properties affect differently.

Thus, the conducted studies have shown that applying ion-ozone and ion-ozone-cavitation processing of grain can purposefully change (improve) its properties depending on the purpose.

\section{Conclusion}

We have developed mathematical models describing changes in the seed and technological properties of barley seeds "Baysheshek". As a result, 156 regression models were obtained on the basis of 23 and 24 fullfactor experiments.. Full-factorial planning of the 23rd and 24th-degree experiments allowed obtaining regression equations, describing changes in the seminal, physico-biochemical and physiological parameters of barley "Baysheshek" and identify the priority grain indicators for compiling a model of linear and non-linear programming, specifying the target and restrictive functions. Complex programming optimization models for the Baisheshek barley grades allowed to establish optimal processing regimes for processing.

\section{References}

[1] A.I. Iztaev, T.K. Kulajanov, M.M. Maemerov, Zh.R. Assangalieva, "Electromagnetic ion-ozone grain processing", presented at the 5-th World Enginecring Congreess (WEC-2013): mat. Intern. scientific and practical work. Conf., Islamabad, 2013.- p. 31. 
[2] A.I. Iztaev, T.K. Kulazhanov, M.M. Mayemerov, Zh.R. Asangalieva, B.A. Iztaev, L.M. Sarlybaeva, Electrophysical methods of grain processing at elevators and grain processing enterprises, Almaty: LLP "LEM Publishing House", 2015, p. 172.

[3] I. Sereev. (2014). Effect of spring biomass removal on expression of agronomic traits of winter wheat, World Applied Sciences Journal. 30 (3). pp. 322-329.

[4] M.M. Maemerov, "Increase in the role of ozone as an environmentally friendly method for treating plant raw materials", in Proc. ISP work. Conf.: Strategy for the development of food and light industry, 2004, pp. 59-60.

[5] A. Iztaev, T. Kulajanov, M. Maemerov, "Application of the electromagnetic ion-ozone nanotechnology in the production of cereals", presented at the Second north and east European congress on food, NEEFood-2013, Pakistan, 2013, p. 34.

[6] A.I. Iztaev, D.R. Dautkanova, N.B. Dautkanova, M.T. Yerbulekova, B.O. Toxanbayeva, "New Natural Sugar Substitute in Baking Industry", presented at the 5-th World Enginecring Congreess (WEC-2013) "Pakistan Engineering Council at National University of Sciences Tehnology", Islamabad, 2013, p. 6.

[7] N.V. Ostapchuk, V.D. Kaminsky, G.N. Stankevich, V.P. Chuchuy, Mathematical modeling of food production processes, Kiev: Vishcha shoal, 1992, p. 175.

[8] M.V. Ostapchuk, Mathematical modeling on the computer, Odessa: Druk, 2007, p. 313.

[9] O. Erkmen. (2001). Uses of Ozone to Improve the Safety and Quality of Foods. Gida Teknolojisi. 5 (3). pp. 58-64.

[10] J.G. Kim, A.E. Yousef, M.A. Khadre. (2003). Ozone and its Current and Future Application in the Food Industry. Advances in Food and Nutrition Research, 45. pp. 167-218.

https://doi.org/10.1016/S1043-4526(03)45005-5 